\title{
ARVIN/CALSPAN ADVANCED TECHNOLOGY CENTER
}

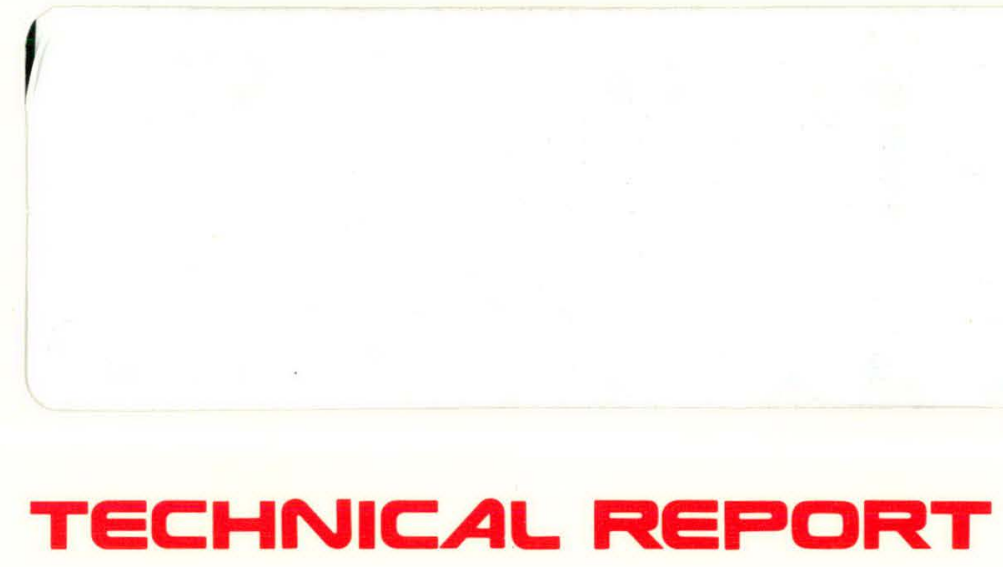




\section{DISCLAIMER}

This report was prepared as an account of work sponsored by an agency of the United States Government. Neither the United States Government nor any agency Thereof, nor any of their employees, makes any warranty, express or implied, or assumes any legal liability or responsibility for the accuracy, completeness, or usefulness of any information, apparatus, product, or process disclosed, or represents that its use would not infringe privately owned rights. Reference herein to any specific commercial product, process, or service by trade name, trademark, manufacturer, or otherwise does not necessarily constitute or imply its endorsement, recommendation, or favoring by the United States Government or any agency thereof. The views and opinions of authors expressed herein do not necessarily state or reflect those of the United States Government or any agency thereof. 


\section{DISCLAIMER}

Portions of this document may be illegible in electronic image products. Images are produced from the best available original document. 
Work performed under the auspices of the U.S. Department of Energy by the Lawrence Livermore Laboratory under contract number W-7405-ENG-48.

This document was prepared as an account of work sponsored by an agency of the United States Government. Neither the United States Government nor any agency thereof, nor any of their employees, makes any warranty, expressed or implied, or assumes any legal liability or responsibility for the accuracy, completeness, or usefulness of any information, apparatus, product, or process disclosed, or represents that its use would not infringe privately owned rights. Reference herein to any specific commercial product, process, or service by trade name, trademark, manufacturer, or otherwise, does not necessarily constitute or imply its endorsement, recommendation, or favoring by the United States Government or any agency thereof. The views and opinions of authors expressed herein do not necessarily state or reflect those of the United States Government or any agency thereof. 

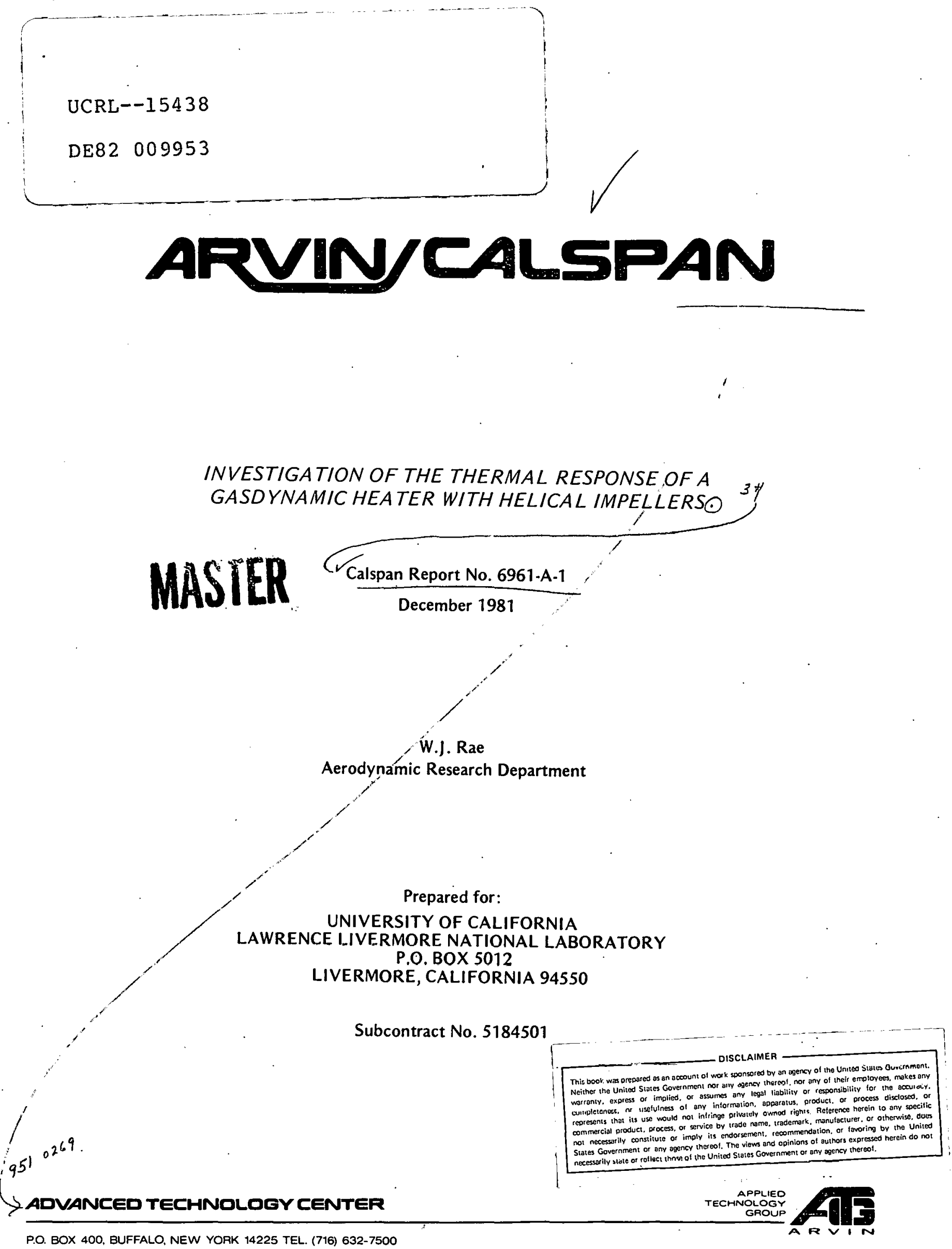

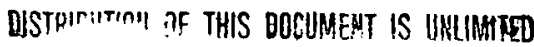


TABLE OF CONTENTS

Section

$\underline{\text { Page }}$

1. INTRODUCTION

2. SUMMARY OF WORK ACCOMPLISHED

2.1) Overall Geometry 3

2.2) Two-Dimensional Planes 3

2.3) Zoning - 3

3. CONCLUDING REMARKS

FIGURES - 6

REFERENCES - 


\section{Section 1}

\section{INTRODUCTION}

A gasdynamic heater, capable of producing contamination-free gas streams at temperatures up to 9000 degrees $K$, is being developed by the Vulcan Project. The design of a cooling system for the case parts and the associated thermal analysis are a critical part of a successful design. The purpose of the present work was to perform a preliminary cooling passage design and complete thermal analysis for the center body liner, end plate liners and exit nozzle.

The approach envisioned for this work was the use of a set of LLNL finite-element codes, called MAZE and TACO2D. These were to be used at LLNL in a series of visits by the Calspan principal investigator.

The project was cancelled shortly after the first of these visits; this report contains a summary of the work accomplished during the abbreviated contract period (Section 2), and a review of the items that will need to be considered when the work is resumed at some future date (Section 3). 
Section 2

SUMMARY OF WORK ACCOMPLISHED

The original statement of work called for completion of the following tasks:

1. Subcontractor's Principal Investigator and Scientific Programmer shall visit the University to familiarize themselves with the University's TACO2D Finite Element Code and the interactive terminal to be utilized in the gasdynamic heat transfer study.

2. Perform a numerical analysis of candidate designs, utilizing the University TACO2D Code and Octopus Computer System.

3. Review the numerical results of the candidate designs, utilizing the University's TACO2D Code and Octopus Computer System.

4. Review the results of the refined designs and prepare a final report incorporating the findings and recommendations of the study.

Item 1 and a portion of item 2 were completed at the time of contract termination. The principal investigator spent the period from September 27 th through October loth at LLNL. Most of this time was spent in using MAZE code ${ }^{1}$ on the Octopus computer system, for the purpose of establishing two of the finite-element meshes to be used by the TACO2D code ${ }^{2}$.

The paragraphs that follow contain: 1.) a description of the overall heater geometry, 2) the two-dimensional "slices" that had been chosen for analysis, by the TACO2D code, of the centerbody liner and exit nozzle, and 3.) some details of the zoning actually used. The question of how to analyze the endplate liner was not addressed. 


\section{1) Overal1 Geometry}

The basic layout is as shown in Fig. 1, which lists the pertinent dimensions.

\section{2) Two-Dimensional Planes}

Because the TACO2D code can analyze only two-dimensional sections, it was necessary to model the actual machine by choosing a set of twodimensional planes. Two of these were chosen, one passing through the centerline of the exit nozzle, and the second lying adjacent to the endplate. These planes are shown in Figs. 2 and 3.

\section{3) Zoning}

The final zoning used for the plane adjacent to the endplate is shown in Fig. 2, (a11 dimensions are in inches). It shows five grooves milled into the vertical side of the liner, and ten around the periphery, back to the point where the heat-transfer rate is expected to be negligible. Each of these grooves consists of a rectangular area, 0.5 inches wide, by 0.1 inches deep, capped by a semicircle of radius 0.25 inches. This detail is shown in Fig. 4. Along the vertical side, these grooves are placed on one-inch centers. Around the periphery, they are placed on rays at ten-degree intervals.

The command file used to generate this mesh is called MAZECF. This file was completed up to, but not including, the assembly step; thus none of the parts have been merged. In addition; some refinements are still required on the zoning of the grooves around the periphery - in particular, some nodes appear to be misaligned on the groove which lies on the transition between the flat vertical wall and the curved portion (especially part number 15). 
The final zoning used for the plane passing through the nozzle centerline is shown in Fig. 3 and.further detail near the nozzle insert is given in Fig. 5. The grooves around the periphery of the centerbody are the same as for the plane adjacent to the endplate. The new grooves (one on the centerbody liner and nine on the nozzle liner) were chosen to have a 3/8-inch width, and a depth such as to leave a minimum metal thickness of $1 / 8$-inch at the base of the groove.

Provision was made for a thermal contact resistance at the surface of the nozzle insert; the element nodes need not match across this boundary.

The command file used to generate this mesh is called MAZCF5. The assembly and merge steps were completed for this case. 
Section 3

CONCLUDING REMARKS

Except for the corrections required to the MAZECF command file (see Section 2.3), no further zoning is required.

The original intention was to use the meshes described above in the program TACO2D. In order to carry out this step, it will be necessary to supply the heat-transfer rates on both the gas and coolant sides. These were to have been taken from the estimates made in Ref. 3 . The preparation of these boundary-condition values had not been started at the time of contract termination. Also not addressed was the question of the values for the thermal contact resistance at the nozzle-insert surface.

Finally, the problem of how to model the endplate has not been considered. 


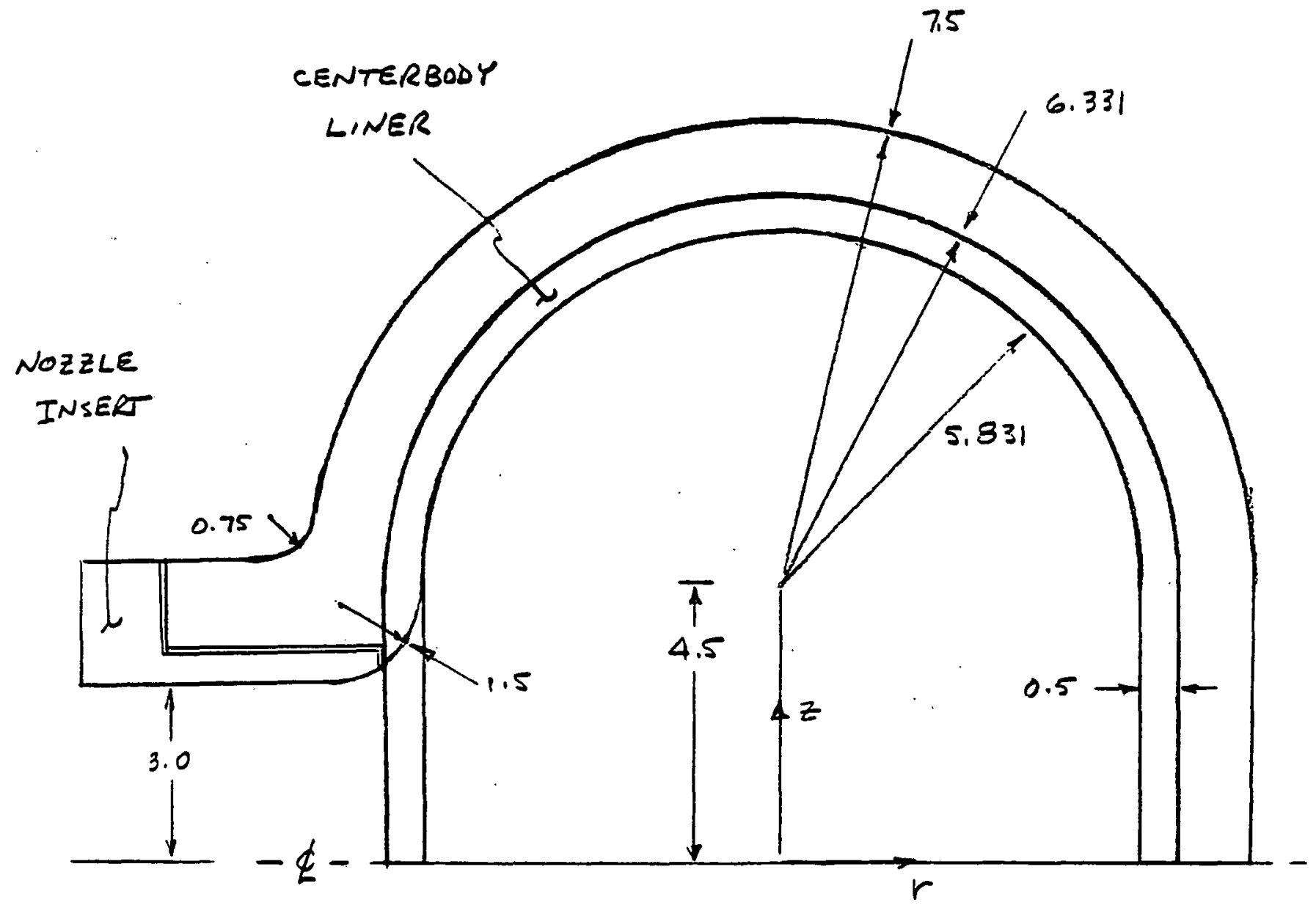

FIGURE 1. PRINCIPAL DIMENSIONS (INCHES) 


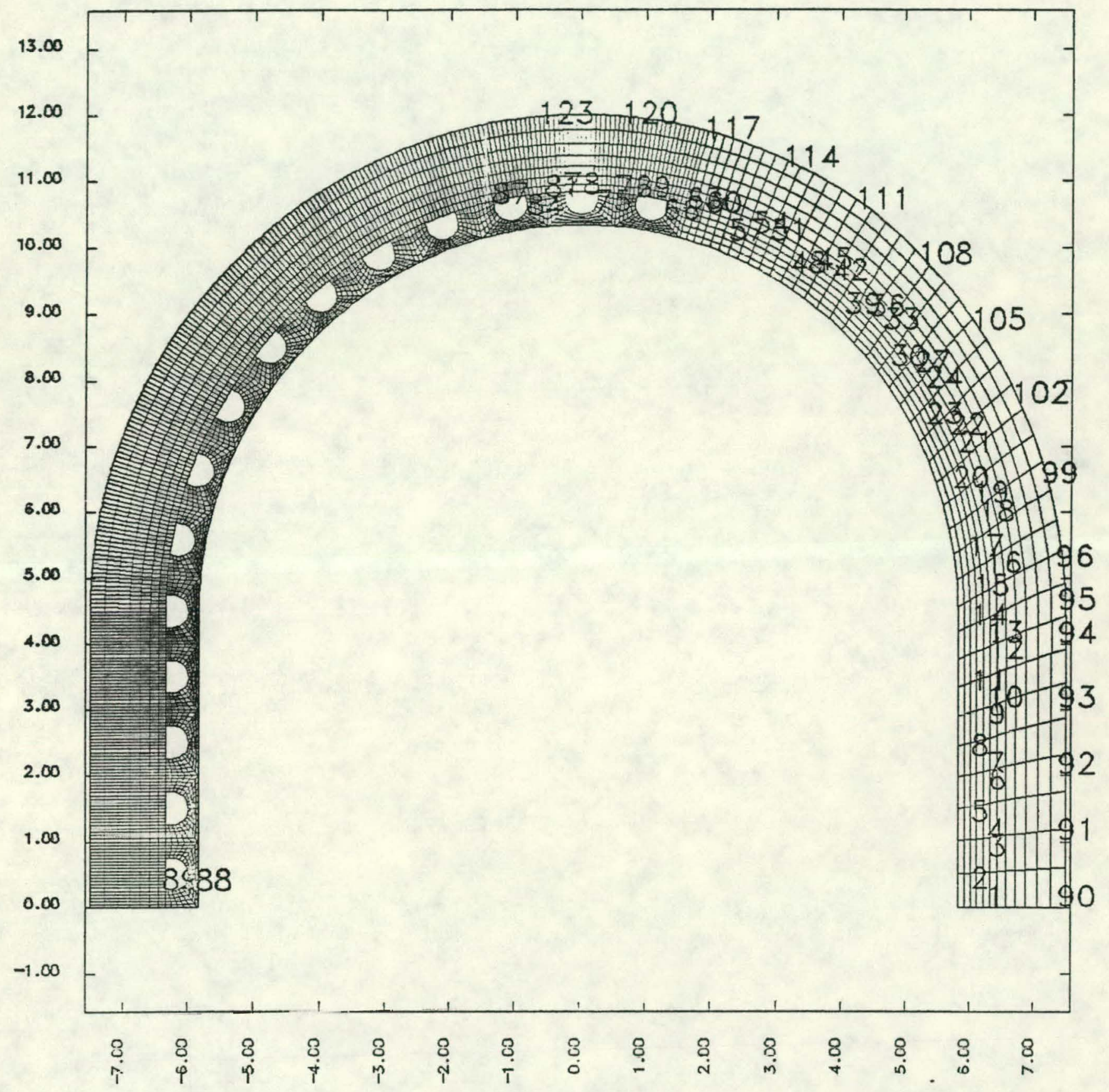

FIGURE 2. PLANE ADJACENT TO ENDPLATE 


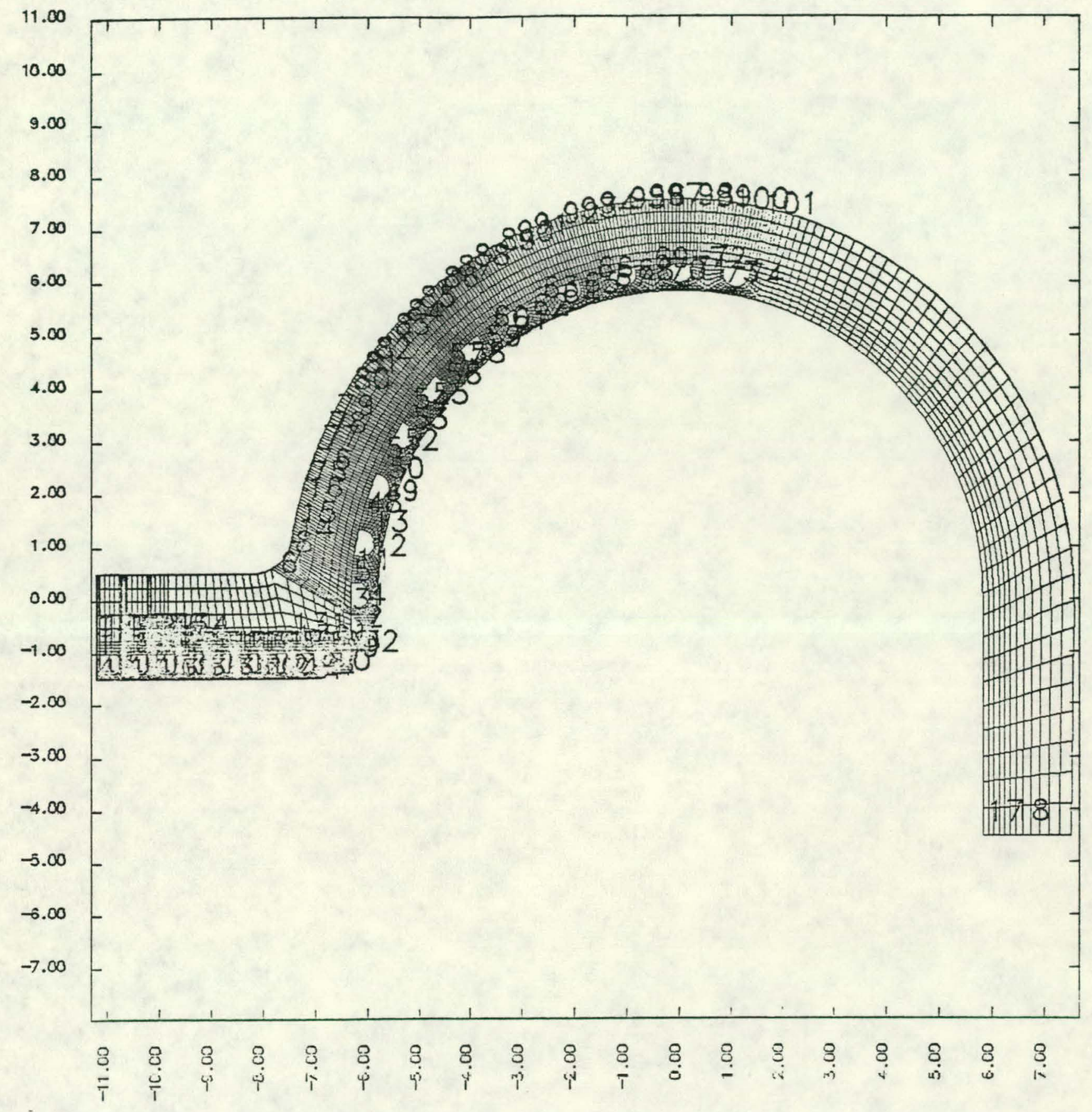

FIGURE 3. PLANE THROUGH NOZZLE CENTERLINE 


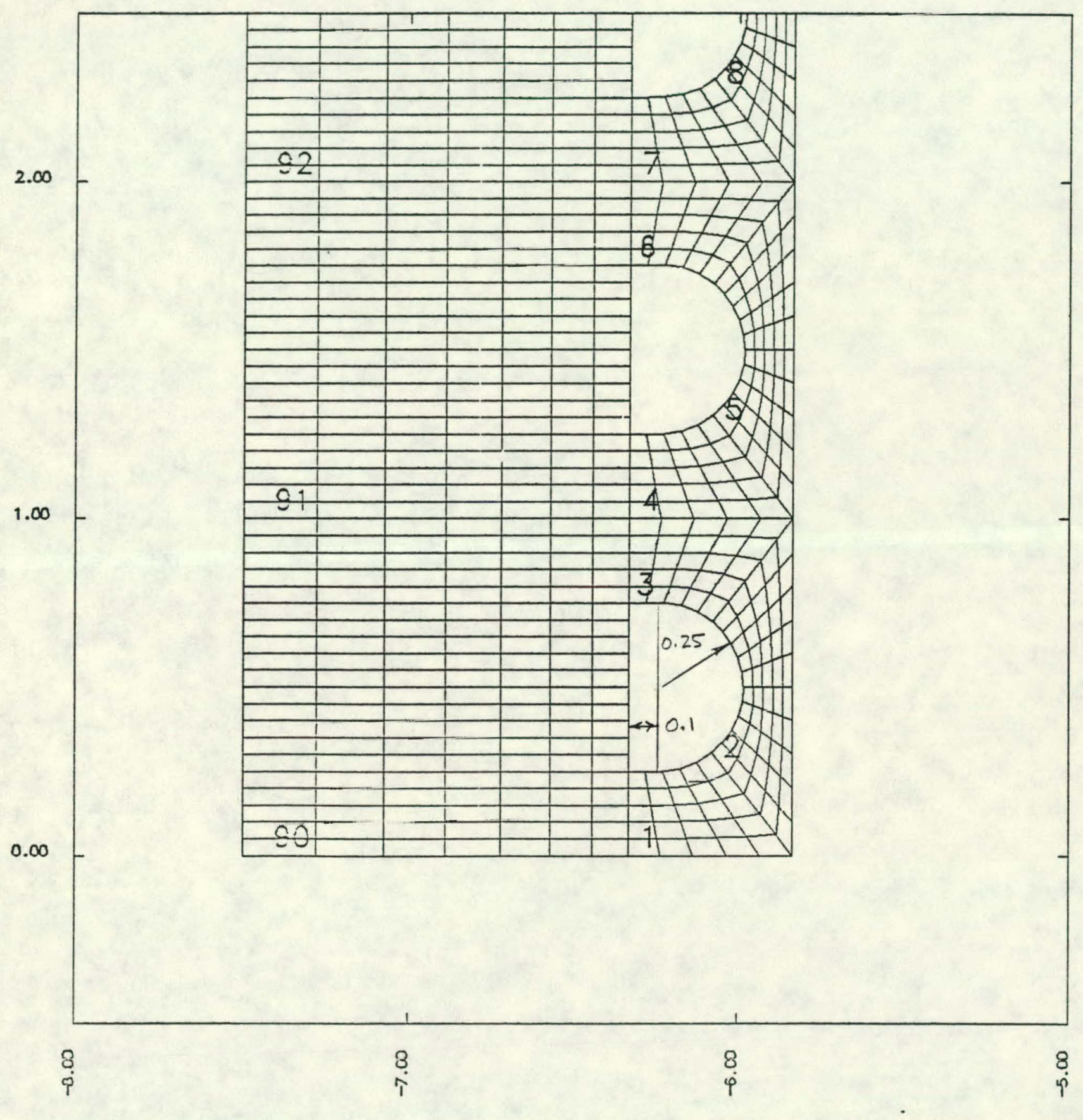

FIGURE 4. GROOVE DETAIL 


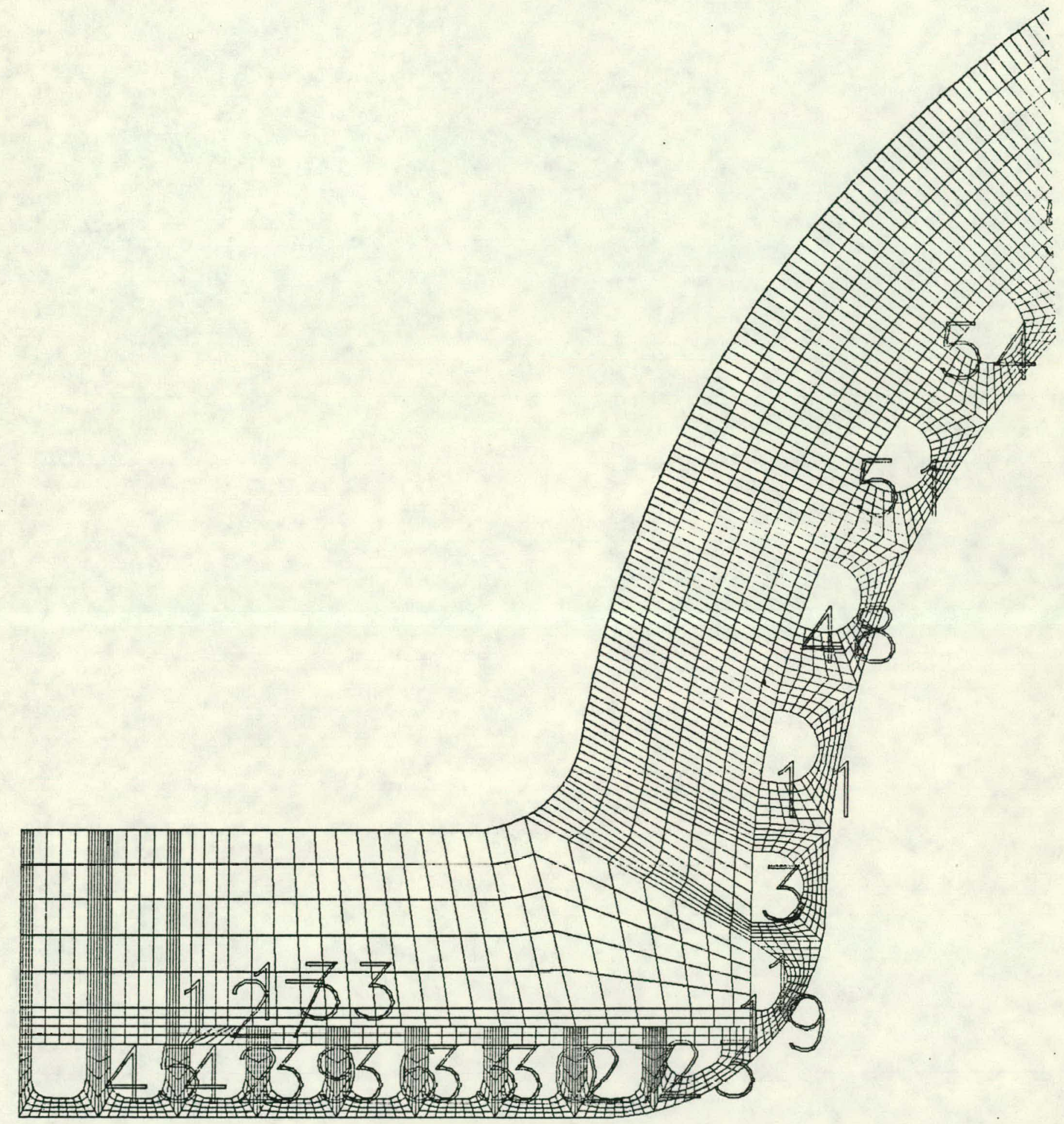

FIGURE 5. MESH DETAIL NEAR NOZZLE INSERT 


\section{REFERENCES}

1. Hallquist, J. 0., "MAZE - An Input Generator for DYNA2D and NIKE2D" Lawrence Livermore National Laboratory, Report No. UCID-19029 (April 1981)

2. Mason, Jr., W.E., "TACO2D - A Finite Element Heat Transfer Code" Lawrence Livermore National Laboratory, Draft revision by P.J. Burns, (April 1981)

3. Russo, A. L., "Project Vulcan - The Development of a Gasdynamic Heater; Vo1. II, Heat Transfer and Performance Analyses for a Gasdynamic Heater with Helical Impellers" Calspan Advanced Technology Center Report No. 6396-A-1 (May 1981) 